\title{
Policy Affairs and Policy Implementation Issues; How Policy Implementation Can Be Effective?
}

\author{
Mohammad Reza Noruzi, EMBA, PhD Student \\ Policy Making in Public Sector \\ Islamic Azad University, Bonab Branch, Iran \\ Young Researchers Club Member, Islamic Azad University, Bonab Branch, Iran \\ Tell: +98- 412-7238893-5, mr.noruzi@modares.ac.ir, mr.noruzi.pnu@gmail.com \\ Farhad Nezhad Haj Ali Irani (Corresponding Author) \\ Public Management, $\mathrm{PhD}$ \\ Islamic Azad University, Bonab Branch, Iran \\ Tel: 98- 0412-7238893-5, Fax: 98- 0412-7238894, Email: F_NejadHajiAliIrani@yahoo.com
}

Received: June 10, 2011 Accepted: June 16, 2011 DOI: 10.5296/jpag.v1i1.718

\begin{abstract}
Policy implementation is one of the important factors in organizing the situation, if a company or in general cannot obey from a good policy implementation strategy it can not be succeed.

This paper aims to study the importance of the policy, social policy and its related materials.
\end{abstract}

Keywords: Policy, policy implementation, policy making 


\section{Introduction}

There are different approaches in management especially in today's turbulent ongoing days. Because environment changes a lot so policies and policy making strategies always changes and becoming more complicated and sophisticated (policy-based management, 2011).

The term policy usually implies some long-term purpose in a broad subject field (e.g. land tenure), not a series of ad-hoc judgments in unrelated fields. Sometimes, however, we conceive of policy not so much as actively purpose oriented but rather as a fairly cohesive set of responses to a problem that has arisen (FAO, 2008).

\section{Policy and its roles}

The role of policy is important in economic, social and political related issues. The search for coordination and coherence of policies should take into account the fact that ideas about policy and its role in development have changed over time, indicating the difficulty to find clarity on the approaches to social investment, poverty alleviation and equity. The result of the implementation of social policies that have gone through profound changes in its design is alarming in terms of deep social inequalities and the welfare of individuals in society (Rittel \& Webber, 1973)

Policy making is often captured by powerful groups and elites, making government policies biased and unaccountable to the majority of citizens. With half the world's population living below the two-dollar -a day poverty line, ineffective social policies can be the spark for state breakdown (Ortiz, 2007, p. 7).

\section{How making policy can be good structured?}

According to the Strategic Policy Making Team Cabinet Office (1999), an effective policy making has lots of competencies for organizations below are some of them:

- Coalition and Joined up - looks beyond institutional boundaries to the Government's strategic objectives; establishes the ethical and legal base for policy;

- Evaluating feedback - keeps established policy under review to ensure it continues to deal with the problems it was designed to tackle, taking account of associated effects elsewhere

- Learning lessons - learns from experience of what works and what doesn’t (Noruzi \&, Hernandez 2010).

\section{Policy and Administration and Why we should obey from policy in the organization}

Policy is a subject area, not a discipline; it borrows from other social science disciplines in order to develop study in the area. The contributory disciplines include sociology, social work, psychology, economics, political science, management, history, philosophy and law (Spicker, 2007).

Policy is very important for us and we should note for this important that policy causes different goals be integrated and this integrations causes government' success. Policy is 
important because it:

- Transfers the value to act;

- Integrates the parts of policy making

- To guide the mission of organizations and firms

- Guide the University towards the achievement of its strategic plan;

- Sets goals

- Improves decision making (policy library, 2011).

\section{The meaning of policy implementation}

According to Lineberry, American Public Policy, policy implementation has been described as follow:

Policy Implementation is the stage of policy-making between the establishment of a policy and the consequences of the policy for the people whom it affects. Also implementation involves translating the goals and objectives of a policy into an operating, ongoing program. Also According to Answers.com, 2011 there are three elements in policy implementation. The 3 elements are:

1. Creation of a new agency or assignment of a new responsibility to an old agency Translation of policy goals into operational rules, and development of guidelines for the program

2. Coordination of resources and personnel to achieve the intended goals (Answers.com, 2011).

\section{Effective factors in Policy implementation}

According to the Mental Health Policy Implementation Guide 2005, there are some important steps for developing policy implementation as comes in the following:

- Local services and local organizations must develop focused definitions of dual diagnosis which reflect local patterns of need and clarify the target group for services;

- Citizens should aware of learning policy implementations;

- All should aware of policy implementation process in their sphere;

- All staff must be trained and equipped to work with dual diagnosis;

- Adequate numbers of staff in crisis resolution, early intervention, community teams and services must also be suitably trained;

- All social economies must map services and need for having good policy and implementing policy; 
- small and time limited local project teams and substance misuse specialists working should prepare the focused definition together with governance guidelines;

- All services must ensure that clients with severe problems and substance misuse are subject to those have a full risk assessment (Mental Health Policy Implementation Guide, 2005).

\section{Applicable Programs for developing policy implementation capability}

There are some applicable suggestions for developing policy implementation capability

•exploring and discussing contemporary issues affecting policy implementation

-recognizing and interpreting the requirements

-identifying and interpreting best practice implementation planning, resourcing, monitoring, evaluating, sustaining and learning

•exploring tools and techniques for transforming policy

•managing stakeholder expectations

-developing skills and behaviors to lead policy implementation(policy implementation, 2005)

\section{Results and discussions}

Dye indicates that implementation involves all of the activities designed to carry out the policies enacted by the legislative branch. These activities include the creation of new organizations in departments, agencies, bureaus, and so on or the assignment of new responsibilities to existing organizations. These organizations must:

- Translate laws into operational rules and regulations.

- $\quad$ They must hire personnel

- Draw up contracts,

- $\quad$ Spend money, and

- Perform tasks.

All of these activities involve decisions by bureaucrats, decisions that determine policy (2005, p. 52 cited in WHO 2005).

Also countries should participate the legitimate agents in policy implementation process this will cause

-Adopt best practice approaches to implementation planning, management and evaluation

-Recognize and apply a whole-of-government approach to seamless delivery of programs and services 


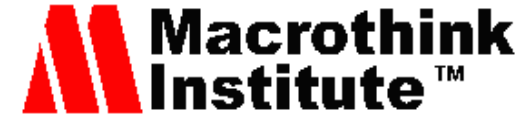

-Recognize the importance of stakeholder expectations and achieving early and low key resolution to potential implementation issues

- confidently meet the requirements of the Cabinet Implementation Unit in the Department of the Prime Minister and Cabinet (policy implementation, 2005)

One critical aspect of policy implementation is the high degree of discretion afforded to the bureaucrats and agency procedures. Administrative decision-making has a significant impact the determination of who receives benefits and who is restricted as a result of the implementation of any policy (WHO, 2011). Administrative decision-making also has a far reaching impact on society as a result of the promulgation of agency regulations, contracting, licensing, inspections, enforcement, adjudication, and the actual discretion for agencies to interpret their own agency rules (WHO, 2011).

\section{About the Authors:}

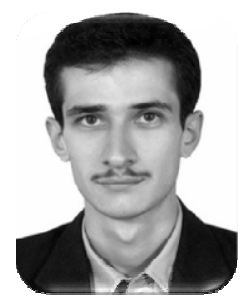

Mohammad Reza Noruzi is a PhD student of public sector policy making in Tarbiat Modarres University in Tehran, Iran. Also is an Executive Master Business Administration. He received a Master of EMBA degree with an emphasis in Strategic Management. And he received bachelor in Public Management. His ongoing research examines issues on Policy Making, Policy coordinating, Multiple Intelligence in management, globalization issues, entrepreneurship, conflicts, international business, organizational Behavior, HRM in domestic and globalization sphere and global staffing challenges. He also teaches policy making in Payam e Noor University in Iran. He has published lots of papers in national and International conferences and congresses and has conducted some research projects.

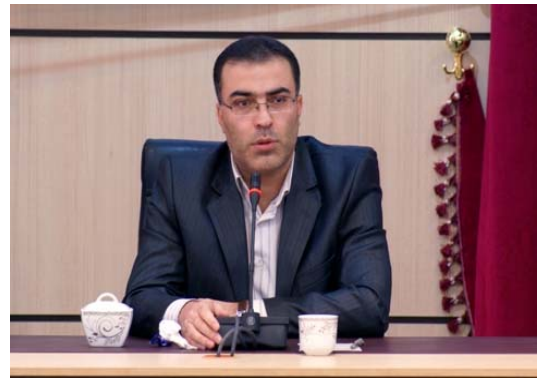

Farhad Nezad Haj Ali Irani is a PhD in public Management. He has guided different students in master degree in public management as advisor and consulter. He has published different books in management area. He is also as a chancellor in Islamic Azad University of Bonab, Iran 


\section{References}

Answers, (2011), define social policy, answers.com available at: http://wiki.answers.com/Q/Define_social_policy

Answers.com, (2011), policy implementation, Available online at:

Danaee Fard, Hassan- Mohammad Rea Noruzi, (2011), Policy and Policy making in Iran: Issues and process, 6th edition of the International Conference on European Integration Realities and Perspectives , Galati, Romania, on May 13th - 14th, 2011. (Forthcoming)

Dean sample, (2005), policy, available at: http://www.polity.co.uk/shortintroductions/samples/dean-sample.pdf

FAO, (2008), Corporate Document Repository, available at: http://www.fao.org/documents/en/detail/18573

http://wiki.answers.com/Q/What_is_policy_implementation

Kilpatrick, Dean G. (2000), Definitions of Public Policy and the Law, National Violence Against Women Prevention Research Center

Mental Health Policy Implementation Guide, 2005, Dual Diagnosis Good Practice Guide, DH department of health.

Noruzi, Mohammad Reza, Jose G Vargas Hernandez, (2010), A Short Note on the Effective Policy Making Strategies in the Public Sector Organizations. Interdisciplinary journal of contemporary research in business, August, Vol. 2. No. 4 (2010). pp. 382-387.

Ortiz, Isabel, (2007), Social Policy, NATIONAL DEVELOPMENT STRATEGIES POLICY NOTES, UNITED NATIONS DEPARTMENT FOR ECONOMIC AND SOCIAL AFFAIRS (UNDESA)

Policy based- management, (2011), what is .com available on line at: http://whatis.techtarget.com/definition/0,,sid9_gci537241,00.html

policy implementation, 2005, policy implementation, available at: file://J:/Policy\%20implementation/policyimplementation.htm

Policy library, (2011), what is policy making role available online at: http://www.newcastle.edu.au/service/policy/definition.html

Rittel, H. \& Webber, M. (1973). Dilemmas in a General Theory of Planning. Policy Sci 4:155-169.

Social Policy, (2006), available at : http://en.wikipedia.org/wiki/Social_policy

Spicker, Paul, (2000), An introduction to Social Policy, welfare and society, available at: http://www2.rgu.ac.uk/publicpolicy/introduction/society.htm

Strategic Policy Making Team Cabinet Office (1999). Professional Policy Making for the Twenty First Century. 


\section{Macrothink

WHO, 2011, World Health Organization, available at:

www.entity/social_determinants/implementation/en/ 